\title{
The Local Church's Defence of Human and Ethnic Rights in Chocó, Colombia
}

\author{
Sandra Milena Rios Oyola ${ }^{1}$ (D)
}

Received: 1 August 2017 / Accepted: 10 October 2017 / Published online: 25 October 2017

(C) The Author(s) 2017. This article is an open access publication

\begin{abstract}
The article analyses the role of the local church in the construction of ethnic organisations in the $1970 \mathrm{~s}-80 \mathrm{~s}$ and later in the defence of human rights in the 1990s2010s in Chocó, Colombia. It studies the transformation of their peacebuilding and humanitarian strategies influenced by liberation theology and the culture of indigenous and Afro-Colombian people. The construction of social memory through workshops has been one of the preferred tools analysed in this article due to their significance in the creation of ethnic organisations and in grassroots peacebuilding. The black social movement accompanied by the local church in Chocó has not only supported the defence of their territory as collective property in an attempt to strengthen their welfare and autonomy but as a form to resisting the violence of the conflict, particularly in the form of forced displacement. This article uses interviews, archive and participant observation in the study of this important transformation that traces one of the most important periods of the conflict in Colombia.
\end{abstract}

Keywords Colombia - Religious Peacebuilding · Social and Cultural Memory · AfroColombian Social Movement · Liberation Theology

\section{Introduction}

One of the crucial components of the conflict in Colombia has been the poor distribution of land and the marginalisation of peasants and poor people, particularly those belonging to ethnic minorities. Chocó is one of the poorest areas of Colombia but rich in biodiversity, where Afro-Colombian and indigenous people have co-existed in harmony with nature and with each other until the incursion of different armed actors

Sandra Milena Rios Oyola

s.m.rios.oyola@hum.leidenuniv.nl

1 International Studies, Leiden University, The Hague, The Netherlands 
during the 1990s. During the 1980s, the missionary teams from the Diocese of Quibdo (local church) had a significant role in supporting the creation of the black social movement that led to the legal recognition of Afro-Colombian communities' rights of ownership over collective land (territorios colectivos) in 1993. These rights were threatened by the violence enacted by the paramilitary armies and their confrontation against the FARC guerrilla. This article explains the role of the Catholic Church in this period and how it shifted their activism towards the preservation of human rights in order to respond to the increasing violence. The analysis is based on the contribution of the local church to the defence of human and ethnic rights through strategies of cultural and social memorialization.

Social memory is the result of an exercise of re-presenting the past according to the demands of the present, which creates continuity and emotional landmarks in a social group (Rios Oyola 2015, 18). Further discussion on the conceptualization of social and cultural memory is presented in the next section. In the case of the Afro-Colombian communities from Chocó, memories of their African ancestry, slavery, forced diaspora, and marooning were brought to the present as part of their continuous defence of the territory. This article argues that the strategies of memorialization led by the local Church are based on the experience of memorialization through workshops, magazines, and performances from the 1970s and 1980s, which is one of the reasons why it has been successful. This article focuses on the role of the local Catholic Church (The Diocese of Quibdó) in the region of Chocó from a historical perspective, covering from the late 1970s until the early 2010s. The research is based on interviews with key informants, who are experts in the field, social leaders, and members of the following religious organisations: Diocesan clergy, the Community of the Claretian Missionaries, Lay Claretians, The Society of the Divine Word, and the Missionary Sisters of St. Augustine. In addition, the author engaged in participant observation conducted through several visits in 2012 and follow-up interviews in 2016; archive research including newspapers, magazines, local assembly reports, and newsletters produced by the Diocese; as well as the analysis of secondary data. ${ }^{1}$

The Diocese of Quibdó has had a very important role in supporting the construction of Afro-Colombian and local peasant communities. The Afro-Colombian identity was a crucial aspect in the creation of the black social movement in the $1980 \mathrm{~s}$ that sought the recognition of their right to collective property (1991-3) as has been demonstrated by the literature in the field (Asher 2009; Berube 2004; Escobar 2003; Almario 2002; Losonczy 1999). Although the role of the local Church in the promotion of rights of ethnic minorities (or ethnic rights) of the Afro-Colombian people has been recognised in the literature, few works have examined this role in detail or observed the role of social memory in their practices (Celis 2016; J. Florez 2012). Later during the 1990s, the Diocese reacted to the increasing presence of armed actors while continuing their work of strengthening ethnic organisations, since the conflict demanded humanitarian support for victims. As has occurred in other regions of Colombia, the local Church filled the gap left by the limited and

\footnotetext{
${ }^{1}$ The part of the fieldwork research conducted in 2012 was developed thanks to the Leverhulme Programme Compromise after Conflict.
} 
inefficient response of the government (Pachico 2015; Tate 2015). This article aims to contribute to the study of the role of religious actors amid conflict and in postconflict scenarios in Latin America (Garrard-Burnett 2011; Levine 2012; Wilde 2015; Bouvier 2013; Comblin 2006; Hayes and Tombs 2001; Henao 2009; MacLean 2006) by focusing on the case of the Diocese of Quibdó. ${ }^{2}$

The Diocese of Quibdó's religious mandates or pastoral options have been inspired by liberation theology, the Vatican Council II, and the Latin American conferences of Puebla and Medellín. According to Father Sterlin Londoño 'the reality in Chocó made it impossible to practice a conservative pastoral work. A pastoral work characteristic of our communities (pastoral propia) was developed during the 1980s-1990s; the pastoral propia creates an ethical dimension, an attitude for accompaniment and resistance' (Conversation with the author, April 2012). This pastoral propia was developed as a response to their concrete situation but also as a result of their process of enculturation and dialogue with the indigenous and Afro-Colombian religious and cultural traditions. The geopolitical reality of Chocó presents high risks for human rights defenders and social leaders, as is explained below. The local Church's rejection of neutrality and their disposition towards the option for the poor made them an important peacebuilding actor but also a target amid conflict. Threats that continue up to date and the murder of several missionaries in the region are evidence of the risk that some missionaries took by following the pastoral options in their communities, particularly regarding their support to the collective property rights over the land by Afro-Colombian communities.

The structure of the article comprises an introductory section on social and cultural memory, followed by an exploration of the role of liberation theology in Colombia, with particular attention to Colombia and the Pacific region. The third section includes a brief history of the local Church in relation to the creation of the ethnic organisation in the region; and finally, an analysis of their peacebuilding and humanitarian work during the highest peaks of the conflict in the region. The analysis is based on memory studies and contributes to the study of the intersection between memory studies and religious studies in the context of peacebuilding.

\section{On cultural and social memory}

The process of remembering past events is individual, subjective and personal; however, all memories are embedded in a social framework. One of the most influential scholars of memory, Halbwachs (1992 [1925], 53), argues that memory occurs in individual thought but we can only make sense of it through the membership to corresponding groups because the 'shared image of the past' that the group develops influences the personal and collective identity of a

\footnotetext{
${ }^{2}$ The region covered by the Diocese is located in Antioquia and Chocó; it is constituted by 250,000 inhabitants, $80 \%$ is Afro-Colombian, $14 \%$ is Mestizo, and $6 \%$ are native population. In the municipality of Bojayá 10,000 inhabitants live. There are more than a dozen religious communities and around fifty diocesan priests in the Diocese.
} 
person. Misztal $(2003,12)$ argues that 'memory is social because every memory exists through its relation with what has been shared with others: language, symbols, events, and social and cultural contexts'. Individuals recollect personal memories and societies share narratives and representations about their past through collective or social memories. Personal memories are in a certain way influenced by society because societies frame social memories in a way that defines what is relevant to remember and what to forget. According to Misztal 'it is society that ensures what we remember, and how and when we remember it' $(2003,11)$.

Cultural memory is linked to the concept of social memory but responds to a different temporality. The main difference is that social memory requires the action of witnesses that tell and reenact their experience, while cultural memory reaches way back in the past and is rooted in traditions (Assmann 2006). Fortunati and Lamberti (2008) argue that cultural memory connects the individual experience to the history of the nation, and how that history and experience will be read in time, individually and collectively. However, the majority of researchers in the field of memory studies use the concepts cultural, social and collective memory interchangeably. Astrid Erll $(2008,2)$ has summarised this complex term under the definition: 'the interplay of present and past in socio-cultural contexts'. This relationship is produced at the individual and the collective level 'or, more precisely, the level of the cognitive on the one hand, and the levels of the social and the medial on the other' $(2008,5)$.

In the case of societies in transition, the pursuit of remembering the past presents the challenge of remembering massive atrocities. Atrocities are by definition unjustifiable and intolerable; they constitute acts of senseless violence, gaps in the narratives of individual and collective identities. For these reason, multiple narratives of social memory attempt to give meaning to meaningless violence. As Rothberg (2009, 313) explains 'memories are mobile; histories are implicated in each other... understanding political conflict entails understanding the interlacing of memories in the force field of public space'. In the case of the creation of narratives of social memory of past massive violence, the search for meaning is important, although it might be filled with contradictions, negotiations and overlapping.

Societies in transition consider the construction of social memory an important step towards reconciliation, revealing the truth about the past facilitates that the new regime distances from it (Rigney 2012). However, in the case of Colombia, during the period studied in this chapter (1970-2010), the conflict was ongoing and memorialization was used as a tool for peacebuilding by grassroots organisations and particularly the local church. This article argues that social and cultural memorialization has been used as tools for peacebuilding in societies in conflict as well as societies in transition. The task of creating meaning of senseless violence can be an empowering task for victims, as well as recovering the truth of the events, and denouncing ongoing violence. Additionally, religion can be a particularly influential arena for the construction of narratives of social memory because the religious framework facilitates the mobilisation of symbols, narratives, rituals and beliefs that can help to create meaning for senseless violence (Rios Oyola 2015, 3234). In what follows, the context of the local church in Chocó, namely the influence of liberation theology, is explained. 


\section{Liberation theology, peace and violence in Colombia}

Liberation theology has followed multiple paths and inspired many theological debates in the last decade, from environmental reflections, claims for gender equality, and migration among other contemporary social problems. Although liberation theology was born among Catholic theologians, it can also be found in many world religions (M. De la Torre 2008). The main principle of liberation theology is the reconceptualization of the Christian faith from the perspective of the poor and the oppressed that aims to achieve liberation from all forms of oppression (Smith 1991, 27). The preferential option for the poor is sustained in the idea that God sides with the oppressed against the oppressors. Liberation theology recognises different forms of violence that ranges from physical and direct violence to institutional violence resulting from inequality, injustice and poverty and imposed by political, social and economic institutions (Gutierrez 1973, 175). Since poverty is a form of structural violence that is sustained by the repression of those who are in power, the option for the poor reflects an option for victims of violence. Celis argues that the theological reflection on the repression against popular sectors and liberation theologians led to a theology of human rights 'in which the suffering of victims of the state was viewed from the perspective of the suffering of a persecuted and martyred Jesus' $(2016,70)$.

This form of violence expands in what Helder Camera called spiral of violence (Camara 1971). As a response to violence, peacebuilding from a liberationist perspective implies tackling these different forms of violence. According to Thia Copper $(2011,542)$, 'Liberation theologians argue that Christians are called to end the spiral of violence and build a spiral of peace'. However, some liberationist interpretations have justified certain forms of violence as legitimate responses to the violence perpetrated by the oppressors. Jose Miguez Bonino, a liberation theologian, 'asserted that frequently conflict, sometimes even violence, is essential in order to transform an unjust order and participate in the creation of a new one (Miguez Bonino 1973, 471-73).' (quoted by Steele 2008, 5-6). Influential liberation theologians such as Camara and Casaldiga were not radical in condemning revolutionary violence as a form of transformation of structural violence, although they chose a non-violent program and Camara considered that revolutionary violence would only increase the spiral of violence (Copper 2011, 547). The clearest example in Colombia of religious justification of revolutionary violence is the priest and co-founder of the sociology department at the Universidad Nacional de Colombia, Camilo Torres, who died during his participation in the revolutionary struggle of the National Liberation Army (Ejercito de Liberacion Nacional - ELN) in 1966.

In 1962, the Catholic Church experienced one of the most major changes in its contemporary history: the Vatican Council II. The Council, called the 'aggiornamento' (bringing up to date) by Pope John XXIII, reinforced changes in the pastoral work towards a stronger commitment to the lived reality of people. Furthermore, Pope Paul VI recommended that 'hence it is clear that men are not deterred by the Christian message from building up the world, or impelled to neglect the welfare of their fellows, but that they are rather more stringently bound to do these very things' (GS 34). However, such involvement with reality implied interacting with an unequal and unjust reality and demanded opting for social justice. 
The changes in the Church were reinforced by the subsequent Latin American Episcopal conferences: Medellín (1968), Puebla (1979), and Santo Domingo (1992). In these conferences, the Church emphasised the necessity to 'put special effort, according to the gospel and our mission in promoting justice and defending the dignity and the rights of the human person' (Puebla 706). The promotion of social justice implicated a strong critique of the neoliberal model that principally affected the poor (SD 181). In this sense, the preferential option for the poor meant the study, critical analysis and action on the causes that created the 'real conditions of poverty' (Castaño 2012b, 438). However, the shift of the Catholic Church, particularly the implications of opting for the poor was not accepted by all sectors of the Church, which generated different trends in the Catholic Church (Bidegain 2004). During the 1960s-80s, base ecclesial communities provided a fecund space for reflexion and awareness in response to the dictatorial repression of several Latin American countries, but their rhetoric and disposition made them often targets of the repression.

In Colombia, during the 1960s, multiple leftist guerrillas were formed while the government condoned the creation of paramilitary groups in their fight against subversive groups (Palacios 2006). The Catholic Church in Colombia experienced polarising trends, on one side revolutionary priests such as Camilo Torres and the Golconda group (Levine 2012, 171-76) and on the other very conservative ecclesial leaders that supported the authority of the government, such as Archbishop Pedro Rubiano Saenz, president of Colombia's Episcopal Conference who supported the armed action against the guerrillas, claiming that the government should 'put the house in order' (Wirpsa 1997 quoted by Brusco 2009, 250). Meanwhile, in Chocó and a large part of the Pacific coast CEBs and other liberation theology initiatives flourished, in part thanks to the bishops' support.

\section{The local context: Chocó}

The territory of Choco is very rich in terms of biodiversity and mineral resources and it has a privileged position that allows communication with the Pacific and the Atlantic oceans. At the same time, Chocó is the poorest region of Colombia. There has been a chronic absence of public institutions that provide health and education and most of the population lacks satisfaction of their basic needs. In Chocó, $70 \%$ of the population lives in poverty, in comparison to the national level of $45 \%$. Additionally, the interests of multinational and national companies and big landowners have damaged the subsistence of the black communities.

The peaceful interaction of black and indigenous communities was a constant in the region, in contrast to other areas of the country that had suffered long standing civil wars and local quarrels. Towards the end of the 1970s, the guerrillas from the FARC-EP - The Revolutionary Armed Forces of Colombia-People's Army (Fuerzas Armadas Revolucionarias de Colombia Ejército del Pueblo) entered the region. At that moment, they were not a threat against the population since the guerrillas did not attack the population directly but they sought to impose their own ideology and punish the transgression of their norms. However, the overall presence of the guerrillas did not bring an immediate outburst of violence since there were no members of the official security forces that could cause armed confrontation in the region. This changed when 
in 1996 paramilitary troops entered in the region and occupied most of the territory; there were joint patrols of the army and the AUC - United Self-Defence Groups of Colombia (Autodefensas Unidas de Colombia).

The Church in Chocó engaged in a non-violent response thanks to the disposition of the missionary teams and their bishop during this time. However, their affinity with liberation theology made them suspicious and untrustworthy by some members of society and the Church. For instance, Father Gregorio Eich claimed that during that time some people raised suspicions against the missionaries saying " "you live here and nothing happen to you that must be because you are with the guerrilla". And even I was told that the guerrillas would say that they were friends with the priests' (Interview with the author, 12 July 2012). Father Gonzalo de la Torre recalls that he was asked to do a pledge when he started the organisational work in the communities. Heriberto Rentaría, a local peasant, asked Father Gonzalo de la Torre to promise that the organisations were not related to communism. Father Gonzalo did the following solemn oath in front of the Afro-Colombian community of the Atrato river side:

I oath, in front of God's word, that the bases of our organisation are completely Christian. We are not doing anything else than what Jesus did when he healed the blind, the deaf, the impaired, and the mute: to make people to see their situation, that they know how to listen their own history of oppression, that they walk by themselves, recovering their autonomy and their own voice, which can only be heard if they act as an organisation. I oath that we do not need to appeal to Marx, not to any other national or international communist leader, for making people to practice the commandment of love in an organisation where everybody feels like siblings, where people can give what they know, what they are, what they have, and what they believe; in a word, that they know how to give their life for others... Christ existed before Marx and before Marx there is in the human being the possibility to love and solidarity. I oath that if we organise ourselves in the name of Jesus Christ, we are the most Christians in the world (G. De la Torre 2008, 99).

Father Gonzalo de la Torre's oath demonstrates the conflicts inside the communities and the hesitation about building organisations in a country in which there is a strong demonization of anything that seems too close to the political left. Paradoxically, at the same time, several of the interviewed religious and missionaries reported that they had to deal with threats by the FARC guerrillas, as is explained below. The option for the poor took form in the Pastoral Agenda through their pastoral options, which included the fundamental option for life, liberating evangelisation, the promotion of Ecclesial Base Communities, Grassroots organisations, Defence of natural resources and of an enculturated Church. In what follows, these options are analysed in terms of their contribution to the defence of ethnic rights and human rights in the region.

\section{The defence of ethnic minorities rights}

The Indigenous Pastoral office was created in 1971, influenced by the developments in social sciences that were supporting processes of social movements based on ethnic 
organisation (Florez 2007). In 1980, the first encounter of Afro-American pastoral on 'Popular religiosity and black culture' took place, which promoted the creation of a specific pastoral for Afro-Colombian communities (CEPAC, Centro de Pastoral Afrocolombiana 2003). The missionaries who had worked with these ethnic groups acquired a new motivation and direction thanks to the new pastoral plan. Some of the consequences of the 'perspective of liberation' taught by the missionaries were that lay people would feel that they needed to do their own liberation 'and that could mean that they do not simply accept what the priest says, they start thinking and sometimes that could leave one [as a priest] in an awkward position (laughs)' (Father Gregorio Eich, Interview 12 July 2012). Nevaldo Perea, one of the first leaders of the black social organisation COCOMACIA - Main Council of the Integral Peasant Association of the Atrato (Consejo Mayor de la Asociación Campesina Integral del Atrato) explains that 'on those reflections on the Bible, we became aware that it was necessary to get organised in order to defend our rights as a forgotten people that was buried deep in the bio-geographical Chocó, a land that is so much sought after by the big national and international capital' (Perea 2012, 47).

According to Aurora Bailon, a Spanish lay Claretian missionary, the missionaries in the middle Atrato created a structured team with clear goals and interdisciplinary perspective. They were focused on cultural, literacy, and productive projects, and the religious/biblical aspects in their work with the community. The education of leaders was very important since the missionary teams' aim was to prepare the replacement for the religious missionaries who would eventually leave:

It was necessary to incite organisational feelings in the communities because as long as the communities organised themselves and they became the subject of their own actions, the continuity of the project would be guaranteed (...) then, we worked a lot for the peasant organisation, and then when we started the process of social organisation, and the peasant association was created, in that moment the ethnic was discovered, and that gave more strength to the identity of the work (Aurora Bailon, Interview 18 April 2012).

The organisational process promoted by the missionary teams led to an increasing awareness of the ethnic component in their struggle. The Apostolic Vicarage of Quibdó produced several booklets, such as the Literacy booklet of the Peasant Pastoral (Cartilla de alfabetización de la Pastoral Campesina) which was initially called Awake with you: Reading our life (Despertar con Ustedes. Leer Nuestra Vida) and was part of the first organisational initiative of the Claretian Missionaries and Lay communities of the middle Atrato. There was a booklet called Reading our Life (Leamos Nuestra Vida) and ACIA's magazine El Atrateño (L. De la Torre and ACIA 2000, 72). During this process, the recovery of cultural memory became a crucial tool for the creation of the ethnic organisations.

\section{Cultural memory and ethnic rights}

Catholic missionaries supported the process of reconstruction of the collective memory of black communities, whose main catalyst of identity at that point had been their 
geographical proximity to rivers where they had been born and their kinship systems instead of narratives about their past. There were no traces of memories about the slavery past in the oral history of the riverside communities; there were no narratives that would constitute them as descendants of African ancestors. However, as some researchers have pointed out in the case of Afro-Colombian communities (Almario 2002; Losonczy 1999; Restrepo 2002), there was a disperse and discontinuous regime of memory that was still present in the everyday language, music, kinship systems and rituals that reflected their African heritage and marks of colonial times. The process of marooning that took place in the humid jungles of the Pacific coast in the eighteenth century created strong cultural connections of the new black free communities with their territory even though they were not openly verbalised.

Thus, the reconstruction of ethnic identity was a work of recognition and transformation of the cultural memory that was already present although not articulated through narrative. It is important to highlight that this was not a passive enterprise, instead, the Afrocolombian inhabitants of these communities actively produced different interpretations and narratives of their ethnicization (Restrepo 2002, 50). Their common ethnic identity, which was shared and socially constructed around the territory helped to reinforce the local ethnic organisations. The territory was rhetorically constructed at the centre of the identity, in which their cultural, social, and religious practices revolved. According to Escobar (2008, 54):

The idea that 'territory' was fundamental to the physical and cultural survival of the communities, and the argument that these communities have unique ways, rooted in culture, of using the diverse spaces constituted by forest, mangrove, hills, and ocean were the two most important conceptual innovations. The experiences of the middle Atrato were important in other respects, such as the development of the technology of territorial and cultural workshops (talleres) that were to become ubiquitous throughout the rivers and towns of the Pacific.

These workshops were led by the local missionaries and they helped to transform the relationship among the communities in terms of territory and ethnicity. The black organisations started constructing a notion of social identity based on narratives of cultural memory that traced a common ethnic background connected to their territory. This process was severely impacted by the increasing attempts by large companies to start a high scale exploitation of the natural resources in the region, such as timber and gold. In the words of one of the leaders of the community:

When we saw that our ancestral territory was in danger, this territory in which we had lived for centuries, even if we did not have a legal property title; we decided to find a way to defend that which had been ours after our fight for freedom: the land that we were standing on (quoted by De la Torre and ACIA 2000, 75).

The local committees were established in 1986; these were the first organisational instruments developed in the black communities. They managed the social and economic activities oriented towards the use of natural resources (De la Torre and ACIA 2000). In 1987, the ACIA (Asociacion de Campesinos Integral del Atrato, later known as COCOMACIA), was established. According to one of the past leaders of 
COCOMACIA, the Church supported the organisation acting as 'advisers and companions, since they accompanied us for everything: in training, in the formulation of proposals to be presented to the government' (Interview, 27 July 2012). During the late 1980s, there was an increasing number of local organisations: 'by 1987, ACIA had reached an incredible goal in its negotiation with the government: the demarcation of six hundred thousand hectares which, although still not legally titles for the organisation, were put under a special management plan based on the cultural practises of the communities' (Escobar 2008, 53). This was a big step compared to the governmental declaration in 1959 that the Pacific lowlands were public empty lands. In 1988, the first board of directors of the ACIA was established (Perea 2012, 49) other, similar organisations followed in subsequent years all over the Pacific coast (Escobar 2008, 53). Several workshops were organised during this period of time by the ACIA and the missionary teams.

\section{The evolution of the conflict and the defence of human rights}

During the 1970s, the presence of drug traffickers interested in obtaining land for producing drug crops increased in the area (Caicedo et al. 2006; Guerrero 2012). In the 1980s the FARC-EP guerrillas (Front 57 and 34), the National Liberationist Army (Ejército de Liberación Nacional - ELN) and the Guevarist Revolutionary Army (Ejército Revolucionario Guevarista - ERG) entered in the Atrato, with the last two groups having less military capacity. The FARC-EP guerrillas focused on the control of the territory, engaging in a fight with the ELN guerrillas. Once the FARC-EP guerrillas were the main armed actor in the zone, the communities felt less threatened because the presence of a single armed actor reduced the amount of combats. Another advantage of the presence of only one group was that this facilitated the possibility of generating dialogues between civilians and armed actors, since there was only one group to discuss the terms of agreement to guarantee the safety of the civilians. The purpose of these dialogues was always 'the defence of the territory and life, to ask them to get out of our territory, let us live in peace, let us live in peace, that was all our denunciation was about' (Male missionary, Interview 30 April 2012).

During the 1970s and early 1980s, the local Church denounced the presence and actions of the armed actors, including the guerrilla groups, against human rights. For instance, one of the denunciations of the Church against these actions was the recruitment of underage Afro-Colombians and indigenous youngsters as soldiers. It was reported during the author's fieldwork that according to for the FARC-EP guerrillas a 14-year-old child is already considered an adult. The guerrilla claimed that if they stopped recruiting minors there would not be more guerrilla men and women, and there would not be a revolution. The missionaries had to be prepared that at any moment in their work in the rural areas they could be intercepted by the guerrilla who would confront them about their accusations.

The local church was on one hand supporting the recognition of the territorial rights of the black communities and on the other responding to the increasing violence resulting from the presence of new armed actors in the zone. In the context of increasing violence, the Church's 'option for life' and their support to the CEBs represented a problem for some sectors of the diocese. Bp. Castaño considered that it 
was necessary to explain to its presbytery that the "option for the poor" could not be reduced to its economic, political, social or cultural dimension'. He claimed in his pastoral letter of the III General Pastoral Assembly of the Vicarage in 1985 that the liberation of people was associated with but not equal to salvation in Jesus Christ (Castaño 2012c). And finally, he reinforced the claim for the rejection of any kind of violence. Bp. Castaño's statement aimed to mitigate tensions and contradictions between members of the Vicarage caused by the renewal of the pastoral agenda and the risks of a misinterpretation of the Gospel message that could lead to violence, as has happened in other regions of Colombia.

In the meantime, the indigenous and black peasant organisations COCOMACIA and OREWA produced regulations for the peaceful coexistence in the villages. The AfroColombian and the indigenous committee were the main authority in these communities. Villagers had to follow these regulations in order to prevent armed actors to have the power of regulating and giving orders in the territory. Additionally, the regulations made clear their position as non-violent civilians. The Diocese, COCOMACIA and OREWA insisted that communities must use their regulations to make clear their position as not partisans of the conflict.

The presence of armed actors was very strong, which meant an increase of murders, displacement, targeting of leaders, and the systematic violation of human rights. Later, the paramilitary group known as Self Defence Peasants from Cordoba and Uraba (ACCU, Autodefensas Campesinas de Cordoba y Uraba) started to work in the rest of the region supporting drug traffic but also projects with high economic potential (Caicedo et al. 2006, 13). This situation led to the strengthening of the missionary team in El Carmen de Atrato, where paramilitary groups arrived. According to Sister Elsa Rueda, member of COVIJUPA:

We started our work there, just like preparing ourselves, because the truth is that the conflict took us by surprise, we did not know how to face it, how to provide orientation. It was like when a monster shows up and one does not know where to look, because he is just everywhere. Then, a team of lawyers was giving us advice (Interview with the author, 19 April 2012).

The missionary team organised workshops with rural leaders and received advice from human rights lawyers. In those meetings, they gathered information about the human rights situation in the zone, received training, and prepared public denunciations through public communications or reports to the Ombudsman. Sister Elsa Rueda argues that:

We had the idea to create a committee of human rights but not to make it visible, simply to do the work very discretely, it was not called committee of human rights, internally we all knew, outside it was an evangelist committee. The strategy was used for the protection of people, and that was how the committee started growing, some people were more committed, some people was very attentive to what was happening, and the urban people and rural people were in key positions, that was very helpful to detect the problems, and many people did not know that this was happening. If a person came to us, because he or she had been attacked by the public armed forces, then we oriented that person to where 
she had to channel her complaint. That helped us to reduce the tension, and the situation of violence, the violation of rights was diminishing (Interview with the author, 19 April 2012).

In 1987, following the recommendation of the Colombian Episcopal Conference, the Commission for Life, Justice and Peace (COVIJUPA) was created due to the violence that had started to affect Carmen del Atrato (Diócesis de Quibdó 1987a). The monthly newsletters produced by the Diocese during that period reflected a preoccupation with the presence of guerrillas and paramilitaries in the territory and the violence that was affecting their communities. During that period, the missionaries of the Divine Verb community had been publicly threatened by the DAS and F2 (a section of the Colombian police forces), and their expulsion from the country was demanded due to denouncing actions against human rights by all armed actors. The Church responded rejecting the threats and making clear that they disagree with any form of violence 'as a forceful system of ideas or social and political behaviour' (Diócesis de Quibdó 1987a). Their newsletters made it clear that they associated themselves with principles of nonviolence, with references to Mahatma Gandhi and Martin Luther King. However, at the same time, they did not consider themselves to be neutral; they took position on the victims' side, and highlighted their religious 'option for life', the Gospel, and the interests of the communities (Diócesis de Quibdó 1987b).

\section{Peacebuilding strategies and the defence of the territory}

The 1990s started with positive achievements for the black communities, such as the enactment of the Law 70 of 1993 that grants collective rights over the territory to black communities and protects the rights of the black ethnic minorities. The formal enactment of the law that recognised collective titling to COCOMACIA started in 1996; however, in this same year the escalation of violence with the presence of paramilitaries started as well. There were joint patrols of the army and the paramilitary groups, which controlled the movement through the rivers Salaquí, Truandó and Domingodó. One of the lasting effects of the paramilitaries' presence was the control they held over the river Atrato, the main means of transportation and resources of the communities. Paramilitaries controlled the mobilisation of people, boats, food, supplies, medicine, and crops, often charging a tax and taking away entire cargo from farmers and fishermen. Both paramilitaries and guerrillas installed check points (Caicedo et al. 2006, 14). The presence of paramilitary troops in the region increased the systematic attack against civilians in joint military operations with the official armies. These actions of terror implemented by paramilitary troops and the Army in Chocó perceived by the missionaries as 'taking the fish's water away', a widespread practice of reducing the support of the civil support to the guerrillas by destroying those communities and reducing the power of their social fabric.

According to the Observatory for Human Rights of the Vice Presidential office, the year with the highest peak of victims in the region was 2000, there were 169 murders, of which 68 were in Quibdó, 25 in Tado and 17 in Carmen de Atrato (Jimenez-Ocampo et al. 2008, 32-33). Actions against civilians included the selective murder of politicians, five massacres between 2000 and 2004 with 142 victims, and 285 cases of 
kidnapping in the same time period. The indigenous groups Embera, Wounan, Kuna, and Nuqui had 44 murders, 44 threats and 38 kidnappings. There were 19 armed confrontations in 2000, 50 in in 2001, 62 in 2002, 33 actions in 2003 and 11 in 2004 (Ibid.).

The local Church felt necessary to implement tools that could help reducing the effects of violence on civilians. New strategies of peacebuilding employed by religious missionaries were influenced by an interpretation of the conflict that observed the close collaboration of the official army with the paramilitary. In the Pastoral Diocesan Assembly in Carmen de Atrato in 1998, Bp. Castaño explains the necessity of transforming their pastoral strategies in order to respond to such a conflict:

The days we are living are not easy at all. In previous Assemblies we had perspectives of our complex Chocoan reality but they have been overwhelmed by generalised violence, which with diverse shapes and faces, has got inside every institution and corner of the social order of our region, of our people. I must confess, for example, that we are experiencing with some of our evangelising groups pain, sadness, deep concern, and total impotence facing acts that are clearly violating human dignity and show total disrespect for life. These acts leave us with big questions about what we have done so far, and what we should do, from the Gospel perspective, in order to radically change this atmosphere of death into the new realities of peace and life for everyone ([1998] Castaño 2012a, 526-27).

The paramilitaries' arrival affected the work of the ethnic organisations. Despite the Law 70 that protected the territory through its imprescriptibility, inalienability, and unattachability, the armed groups exercised a territorial, administrative - political and economic control de facto' (Berube 2004, 731). From that moment onwards, the priorities were set around resisting the armed conflict. Leyner Palacios, a local leader working with the missionary teams for several years, evoked in this interview the shift in their work of accompaniment to the communities:

From the end of 1996, half year through, the situation starts to change and the problems of the communities revolve around the armed conflict, for instance they say, 'see they have raped my daughter, killed my brother, they took this person, this other person is disappeared' then, the situation is more complex. In that sense, we played a role by accompanying the community... so the armed actors would at least respect people's life. Something else we had to take care of was transportation; it was almost like doing charity, because the small things that could be acquired in the communities were there because we had taken them there. We had to implement community shops, first aid kits, threshing machines, and other things to help people to subsist the blockade imposed by the armed actors (Leyner Palacios, Interview with the author 19 April 2012).

In previous years, the Diocese had insisted on avoiding charity work with the communities and instead supported projects of self-development. An important transformation that occurred with the increasing violence was to practice charity with the victims who stayed in their communities and those who were displaced. The joint work 
of the missionary teams and COCOMACIA helped to establish some strategic projects that would help to reduce the displacement of the communities. One of these actions was the community boat called Noah's Ark. This project consisted in the control and supply of local community shops and transportation of the products of the peasants to Quibdó, Turbo and Cartagena. This initiative was supported by the German NGO Misereor.

Another important strategy implemented to counter the displacement of population in the riverside communities was the creation of Humanitarian and Community centres in Buchadó, Tagachí, la Loma, Opogadó and Isla de los Rojas. This initiative was supported by COCOMACIA, the Diocese, PCS (Project Counselling Service), and ACNUR. More than 4000 peasants from Alto Baudó and other communities arrived in Quibdó due to threats made by paramilitaries in 2000 and 2001 (Caicedo et al. 2006, 22). The Humanitarian and Communitarian centres were created across riverside villages in order to receive forced displaced people who were just fleeing or displaced people who were in the first stage of return. The centres received the displaced population until the highest risk had passed and they were able to get humanitarian help. Their purpose was to avoid a potential humanitarian crisis that could result from the arrival of large numbers of the displaced communities to cities such as Quibdó, Turbo and other urban municipalities.

The most demanding crisis occurred in 2002, during a confrontation in the municipality of Bellavista in the Pacific lowlands of Colombia in Bojayá, the FARC guerrillas launched several homemade mortars assembled with gas cylinder parts (known as pipeta in Spanish) against the AUC paramilitary army, who were using the church San Pablo Apostol as a shield. In the church, over three hundred Afro-Colombian civilians were seeking protection. The pipeta reached the church instead of the paramilitary group, and as a result, a nondetermined number of victims (but officially recognised as 79 people) were killed (GMH-CNRR 2010).

During this period, the Interethnic Forum Solidarity Chocó (Foro Interetnico Solidaridad Chocó, FISCH) was created. The Forum, a space of coordination and conciliation, dialogue and discussion for ethnic and social organisations in Chocó, focuses on the construction of a regional peace agenda constructed by the communities, organisations and for the communities and organisations. FISCH's work has been supported and advised by the Diocese of Istmina-Tadó, the Diocese of Apartado and the Diocese of Quibdó (Diana Rojas, FISCH interview 10 April 2012). In addition, COVIJUPA has carried out several workshops with victims, most of them women. These groups have been oriented towards improving the material conditions of peasant families but they were also working as therapeutic centres for victims.

The Diocese of Quibdó has engaged in dialogues with different actors that are involved in the conflict at a social, economic, and armed level (Hernandez 2012). It has created opportunities of dialogue with and between international funders, government agencies and ethnic organisations. However, during the height of the conflict the dialogues that needed more attention were with armed actors. According to Jesus Parra, previous director of the Social Pastoral office of the Diocese of Quibdó, the pastoral dialogues 'are tools to achieve understanding, comprehension, and agreement, from the perspective of the Gospel, with the purpose of caring the life of every person' (Hernandez 2012, 321). 
Some religious and lay missionaries have been directly affected by the violence in the region despite the safety measures outlined above, such as Miguel Angel Quiroga, Iñigo Eguiluz, Jorge Luis Mazo and Yolanda Ceron, murdered by paramilitaries. The missionaries are martyrs whose deaths are important milestones in the memory of the struggle of the Diocese. However, as Parra explains 'those deaths hurt, but it hurts more those 800 or 1000 dead peasants in the Atrato since 1997' (Lopez 2005). The memory of the martyrs has been incorporated in a larger narrative of the victims (lay and religious) of the conflict in Chocó.

The constant displacement that these communities experienced in addition to the weak institutional response and the discrimination they suffered by these institutions contributed to strengthening a new perception of the conflict: the motivation of armed actors was not only to eliminate the antagonist armed actor, but precisely to empty the lands from the presence of the indigenous and Afro-Colombian communities, following the precepts of a scorched earth policy. Thus, a new stage of conflict represented the consolidation of the paramilitary project after the most violent acts took place during the conflict. According to Jesus Florez:

This means that there are fewer massacres but the military confrontation continues. They continue to attack the civilian population in military confrontations. In that context, it becomes evident that the conflict is not exclusively military, but the military actions are an argument to achieve an economic goal. The first economic goal is the consolidation of the agro-industrial model of some products such as banana and palm tree, but fundamentally the extractivist model in the region (Jesus Florez, interview with the author14 July 2012).

These events were denounced by the Diocese, who was particularly concerned with the acts of the paramilitary groups who have 'the need of cleansing the territories' in order to get rid of those who could oppose their decision of 'implementing development' (COVIJUPA 2006, 10). In a Pastoral Letter signed by six bishops of the Pacific Coast, they denounced the paramilitary strategy as presenting an anti-insurgent struggle, but its main interest was the disestablishment of the region and provoke the forceful displacement and exile of thousands of inhabitants of the Pacific coast (Giron et al. 2012) This change of interpretation of the conflict does not only complement the first explanation of 'taking the fish's water away' but is a more accurate description of the transformation that the conflict would take during the decade (2002-2012).

\section{Social memory: the work of the Commission Life Justice and Peace (COVIJUPA)}

The shift in the interpretation of the conflict, as was explained by Jesus Florez, helped to motivate the creation of new long-term pastoral strategies implemented to resist the conflict. Those strategies included a continuous denunciation of the criminal acts of the armed actors against Afro-Colombian and indigenous communities as well as the illegal use of the territory; denunciation of the collusion between paramilitary and army groups which has been published in several reports and in open letters to the 
president; a collection of information about human right crimes; the project of recuperation of the space of Atrato river called Atratiando; the document Declaration for Peace and Life (Declaración por la vida y por la paz) elaborated by each one of the communities; accompaniment and support of victims' groups; the Peace week where the different peace initiatives across the region come together in Quibdó; and the support of the creation of a Regional Peace Agenda through the Inter-ethnic Forum Chocó Solidarity.

The Diocese made the most of the reduction of violent attacks by collecting victims' testimonies and starting the more systematic work of recovering historical memory of atrocities and human rights crimes in the region. Father Ulrich Kollowitz, a German priest who has been over 30 years in the region and is member of COVIJUPA, explains this shift in the situation of conflict and how the Diocese responded:

During those years we had to do a firefighter job, constantly fighting fires. We often had to run from one community to another, it was practically useless to make a work plan, the plan was made for us, the armed actors imposed our work plan because we had to react to every situation. That situation has changed in the last years; we have been able to dedicate more time to collect the information for [building] a historical memory. You can see what we have been doing in the chapel, we started doing that in 2007 ... because in the decade 2010 we had to run less to fight fires, but in that period, at the end of the 1990s and beginning of 2000 , there was a constant work accompanying journeys for supplying community shops, to prevent them to be plundered by paramilitaries or guerrilla, that was our main job in 1998 (Father Ulrich Kollowitz, Interview with the author 25 April 2012).

After the years of more extreme violence had passed, COVIJUPA's work could finally take off. This article has focused on the work of COVIJUPA due to its attention to the social construction of memory of the atrocities that have taken place in Chocó although COVIJUPA, the Social Pastoral, the Afro Pastoral and the Indigenous Pastoral work in an integrated manner. The work of these different dependences of the Diocese is all equally inspired in the pastoral options, which are constantly updated and oriented towards accompaniment, support and denunciation. These commitments have been reaffirmed in the Pastoral Letter 'Land and Territory, God's gift for life' (Giron et al. 2012) signed by the bishops from the Pacific region (Tumaco, Guapi, Buenaventura, Istmina-Tadó, Quibdó, and Apartadó).

This team developed a consistent accompaniment to victims; they supported the creation of memorialisation events, and the regular publication of the magazine Voices of Black, Indigenous, and Mestizo people (Las Voces del Pueblo Negro, Indígena y Mestizo). This annual publication started in 2004 coordinated by COVIJUPA and supported by several agencies at various stages of its publication: Catholic Relief Services, Misereor IHR Hilfswerk, Christian Aid and Project Counselling Services, among others. The database on crimes in the magazine has been built through a network of different local communities of the Diocese, missionaries, social leaders, national and international NGOs and international organisations such as ACNUR. The work of systematisation is important in transforming the construction of social memory 
at a social level into a work of denunciation in the legal arena (Elster 2004; de Brito et al. 2001). The Commission also registers the ethnic background of the victim, not only if a person was indigenous but to which indigenous group they belonged (if she was Embera-Chami or Embera-Wounan for instance). The commission only registers civilians (those who are not holding any arms); for them, any person is a civilian until they get into a group 'with uniforms and guns'. Cooperation of civilians to armed groups does not qualify as membership to an armed group because it is very difficult to discern 'forced' cooperation from sympathy with the groups.

The collection of information is done through strict confidentiality and the cases that are part of a denounce need the previous agreement of victims before making them public. This has proved to be a challenge in at least two situations: when the event (murder, aggression, disappearing) is too recent and when it is related to sexual violence. There are only three or four of these cases registered in COVIJUPA's database for 2011 and 2012, even if there were more than thirty cases in the city. It is possible that some of those people who were murdered were people who had been involved with illegal groups. Many of the murders were allegedly committed by the police or other official forces, thus appearing in the official records as common crime. This is a reason why COVIJUPA cannot include them in the list of crimes against human rights. The commission can only rely on the victims' testimonies for doing so, but the victims feel that it is easier to talk about cases that happened in the 1980s as opposed to those that are more recent. Regarding cases of sexual violence, it has been hard for the commission to register them. According to Ursula Holzapfel, a German lay missionary who has been in Chocó for over 30 years working with the local grassroots church:

That is a point that is rarely touched. Sexual violence against women in armed groups is a topic that is widely discussed in the organisations, but there are very few women who really speak about this. That is a job that needs to be individual, very seldom with two or three women, but that cannot be addressed in big groups. That is a job that needs time, lots of time. We hear cases nowadays, and we have always thought that we knew most of the cases in the field, but we were mistaken, we have received new cases because only now people would come and talk (Interview with the author, 28 April 2012).

COVIJUPA as part of the local grassroots church allows the feeling of confidentiality for the collection of testimonies related to sexual violence, an activity that would probably be more difficult to achieve by other organisations. COVIJUPA also supports activities of memorialisation through the relocation of the private individual memories of victims into the public communal space of the Church. Following that goal, they have created 'Memory chapels', two in Quibdó, one in Carmen de Atrato and one in Lloró. In those chapels, they have almost 300 photographs of victims with their name, age, armed actor who perpetrated his/her murder and place and date where the murder occurred. In cases in which the families did not have a photograph of the victim they replace it with the picture of an illuminated cross. Victims carry these cards when they conduct manifestations through streets in Quibdó.

COVIJUPA's accompaniment to families consists of emotional and social assistance and legal training on their rights as victims (and particularly as collective 
victims). They encourage victims' families to write their own memory book-a small notebook where they can have 'conversations' with their deceased relatives and can write something about the victims to those who do not know them or to their relatives. COVIJUPA's psycho-social support for the families aims towards the healing of victims' families. COVIJUPA also coordinates small groups where victims can get some improvements in their quality of life. These groups come together in Quibdó, Carmen de Atrato, Murindó and Bellavista.

They are dedicated to the production of handicrafts, baked goods and small-scale farming. The aim of this kind of accompaniment is to create a sense of purpose for the members who are victims of displacement, those who have returned or are 'forcefully emplaced' in the territory. Once per month COVIJUPA organises a mass in the chapel of the convent, celebrating the anniversary of deaths of relatives, Christmas or other important dates. COVIJUPA works with 800 victims; however, those who regularly attend its activities are around 150. Part of their work is to create a network of support for victims, most of whom live in conditions of extreme poverty. Ursula Holzapfel explains about their work at COVIJUPA:

accompaniment to victims' families, building a database [of human right crimes] and accompanying a process, a petition to the Inter-American Court for the murders of Father Jorge Luis Mazo, volunteer Inigo Iguiluz and Miguel Quiroga, killed by the paramilitaries. We presented those cases but we did not want to present only the cases of our partners in the Diocese but also all those cases that we knew about, and those were at that moment around 140, but now we are in 918 cases in the Diocese. The first case was in 1963 but those very few during the first years, and they started strongly increasing in 1997. The years before that, particularly since 1992 there were cases in La Carretera ... those cases were known because the people were in the jurisdiction of the Diocese, or their relatives live here and they have killed them in other areas. For instance, many people from Carmen de Atrato have been killed in Jerico, Bolivar, many people from here in Yuto have been killed in Istmina, people from Bojayá have been killed in Riosucio, or the displaced that are living in Riosuscio they are coming from Curbarado, Jiguamiando. They are all in our database. (Ursula Holzapfel, Interview 28 April 2012).

Using this information does not only help building a historical memory of the violence but it also has the potential to reach a legal arena. Keeping and publishing a record of crimes provides evidence of the systematic trajectory of crimes in the region. The recognition of the criminal events occurred in the middle Atrato as part of a widespread attack against civilian population with a discriminatory element would open the possibility for a trial in an international court. Crimes against humanity as they are codified in article 7 of the Rome Statute of the International Criminal Court (ICC) comprise inhumane acts such as murder, extermination, rape and persecution, which cause great suffering or serious injury to both mental and physical health. These acts are committed 'as part of a widespread or systematic attack directed against any civilian population, with knowledge of the attack'. 
These strategies have contributed to enhancing a solid network of humanitarian work focused on human rights, ethnic and victims' rights through the work with organisations in the region, such as FISCH, Victims' associations, COCOMACIA, OREWA, among others. The empowered communities and victims have proved to be essential for the next step in the transformation of the conflict, namely, the peace negotiation between the government and the FARC in 2016. During this stage, victims' leaders participated in the negotiating table in Havana, where their experience of the conflict and their demands were listened to. Later, in December 2015, the FARC visited Bojayá to issue a public apology for the massacre committed during the confrontation between the paramilitary troops and the guerrilla in 2002. During the campaign for the plebiscite that would have approved the peace process in 2016, the local church also actively supported the campaign at a local and regional level. Currently, in the context of transition, the local church and local organisations continue to denounce the ongoing and new manifestations of violence against communities and social leaders in the region.

\section{Conclusion}

The local church in Chocó has led an important work of resistance to violence in the region, which has been primarily successful in preventing an even bigger humanitarian crisis resulting from the forced displacement in the region. The centrality of the defence of the territory as a locus of the identity of Afro-Colombian and indigenous communities has evolved into the discourse that sustains the resistance to armed actors. The practices of social memorialization that took place in the form of rituals, participation in the creation of documentation, workshops, among others, were used initially to strengthening the cultural memory of the Afro-Colombian communities, which later was used in the work of historical memory conducted by COVIJUPA. This work intended to denounce structural and direct violence in the region. Following the liberation theology principles, the idea of structural violence was important to understand the conflict and to construct a line of continuity between the diverse types of violence and the marginalisation that had been suffered there.

The local church's efforts to reconstructing social memory responds to the demand for the defence of ethnic rights and has been broadened to resist denial and silence in an aim to support victims' and human rights. The analysis of the local church's strategies of mobilisation and construction of the cultural and social memory of different forms of violence experienced in the region, demonstrates the challenges and advantages of using memorialization as a tool for peacebuilding amid conflict. The changing dominant interpretations of the conflict (such as 'taking the fish's water away' or the disestablishment of the region) show how narratives of social memory can change, transform and overlap according to the needs of the present. The case of the local church in Chocó highlights the commitment for peacebuilding by the church at the grassroots in Latin America, and how far they can reach when supported by the local bishops. This case is far from being unique and further research in similar and diverse contexts will help to understand the connection between cultural and social memorialization and the strategies employed to overcome the legacy of conflict and violence in the region. 
Open Access This article is distributed under the terms of the Creative Commons Attribution 4.0 International License (http://creativecommons.org/licenses/by/4.0/), which permits unrestricted use, distribution, and reproduction in any medium, provided you give appropriate credit to the original author(s) and the source, provide a link to the Creative Commons license, and indicate if changes were made.

\section{References}

Almario O (2002) Territorio, Identidad, Memoria Colectiva Y Movimiento Étnico de Los Grupos Negros Del Pacífico Sur Colombiano: Microhistoria Y Etnografía Sobre El Río Tapaje. J Lat Am Anthropol 7(2): 198-229. https://doi.org/10.1525/jlca.2002.7.2.198

Asher K (2009) Black and green: afro-Colombians, development, and nature in the Pacific lowlands. Duke University Press, Durham

Assmann J (2006) Religion and cultural memory: ten studies. Stanford University Press, Palo Alto

Berube M (2004) Derechos Étnicos Y Territoriales de Las Comunidades Afro-Colombianas En Los Territorios Colectivos Del Pacífico Sur Frente Al Conflicto Armado. Universidad Nacional de Colombia : COLCIENCIAS Colombia, Bogota

Bidegain AM, ed. (2004) Historia Del Cristianismo En Colombia: Corrientes Y Diversidad. Bogota: Taurus. http://www.librarything.com/work/3413327

Bouvier V (2013) The role of the churches in the struggle for peace. Colombia Calls. http://vbouvier. wordpress.com/2013/06/14/the-role-of-the-churches-in-the-struggle-for-peace/

Brusco E (2009) Colombia: past persecution, present tension. In: Sigmund PE (ed) Religious freedom and evangelization in Latin America: the challenge of religious pluralism. Wipf and Stock Publishers, Eugene Oregon, pp 235-253

Caicedo L, Manrique D, Echeverría DCM, Pulido B (2006) Desplazamiento Y Retorno. Libro 2. Espirales Del Desplazamiento. El Retorno a Bojayá, Chocó. Coleccion Textos de Aqui y Ahora. ILSA, Bogota

Camara H (1971) Spiral of Vilence. http://www.alastairmcintosh.com/general/spiral-of-violence-camara.pdf

Castaño J (2012a) “1998. Saludo a La Asamblea Diocesana de Pastoral, Carmen de Atrato, Diciembre.” In Un Obispo En Una Epoca de Cambios. La Iglesia Del Vaticano II En Quibdó. Jorge Iván Castaño Rubio, Cmf. Pensamiento Y Obra, edited by Jesus Florez, 526-36. Colombia: Fundación Universitaria Claretiana

Castaño J (2012b) “2001. Teología Y Vida de La Iglesia En Algunos Momentos Significantes Del Continente Latinoamericano." In Un Obispo En Una Epoca de Cambios. La Iglesia Del Vaticano II En Quibdó. Jorge Iván Castaño Rubio, Cmf. Pensamiento Y Obra, edited by Jesus Florez, 427-46. Colombia: Fundación Universitaria Claretiana

Castaño J (2012c) “1985. III Asamblea General de Pastoral Del Vicariato.” In: Un Obispo En Una Epoca de Cambios. La Iglesia Del Vaticano II En Quibdó. Jorge Iván Castaño Rubio, Cmf. Pensamiento y Obra, edited by Florez, Jesus. Fundación Universitaria Claretiana, Colombia, p 461-65

Celis L (2016) “The Legacy of Liberation Theology in Colombia: The Defense of Life and Territory." Edited by Jennifer Scheper Hughes and Maria das Dores Campos Machado. Lat Am Perspect 43 (3): 69-84. doi: https://doi.org/10.1177/0094582X16639270

CEPAC, Centro de Pastoral Afrocolombiana (2003) Historia Del Pueblo Afrocolombiano - Perspectiva Pastoral. Anexo No. 1 Encuentros de Pastoral Afroamericana. http://axe-cali.tripod. com/cepac/hispafrocol/index.htm\#con

Comblin J (2006) "Ch. 6. The theme of reconciliation and theology in Latin America." In Reconciliation, nations and churches in Latin America, edited by Iain S. MacLean, 135-70. Hampshire: Ashgate

Cooper T (2011) Liberation Theology and the Spiral of Violence. In: Murphy A (ed) Blackwell Companion to Religion and Violence. Blackwell Publishing, Sussex, p 541-53

de Brito AB, Enríquez CG, Fernández PA (2001) The politics of memory: transitional justice in democratizing societies. Oxford University Press, Oxford

De la Torre M (ed) (2008) The hope of liberation in world religions. Baylor University Press, Texas

De la Torre L, ACIA (2000) Historia de La Asociación Campesina Integral Del Atrato ACIA. http://www.rds. org.co/aa/img_upload/c1a230c6696a0e3d3ded4cbdbe1edfd7/acia.pdf

Diócesis de Quibdó (1987a) Carta Mensual

Diócesis de Quibdó (1987b) Carta Mensual

Elster J (2004) Closing the books: transitional justice in historical perspective. Cambridge University Press, Cambridge; New York

Erll A (2008) Cultural memory studies: an introduction. In: Nünning A, Erll A (eds) Cultural Memory Studies: An International and Interdisciplinary Handbook. Walter de Gruyter, Berlin, pp 1-18 
Escobar A (2003) Displacement, development, and modernity in the Colombian Pacific. Int Soc Sci J 55(175): 5-5. https://doi.org/10.1111/1468-2451.5501019_14

Escobar A (2008) Territories of difference: place, movements, life, Redes. Duke University Press, Durham

Florez, Jesús Alfonso (2007) Autonomía indígena en Chocó. Quibdó: Centro de Estudios Etnicos

Florez, Jesus, ed. (2012) Un Obispo En Una Epoca de Cambios. La Iglesia Del Vaticano II En Quibdó. Jorge Iván Castaño Rubio, Cmf. Pensamiento Y Obra. Colombia: Fundación Universitaria Claretiana

Fortunati V, Lamberti E (2008) Cultural memory: a European perspective. In: Erll A, Nünning A (eds) Media and cultural memory: an international and interdisciplinary handbook. Walter de Gruyter, Berlin and New York, pp 127-137

Garrard-Burnett V (2011) Terror in the Land of the Holy Spirit: Guatemala under General Efraín Ríos Montt, 1982-1983. Oxford University Press, New York; Oxford

Giron G, Alvarado H, Garcia J, Cadavid F (2012) Carta Pastoral Tierra Y Territorio Don de Dios Para La Vida. Equipo Misionero Centro Pastoral Nuestra Señora de Guadalupe

GMH-CNRR (2010) Bojayá: La Guerra Sin Limites. Ediciones Semana, Taurus, Bogota

GS - Gaudium et Spes

Guerrero J (2012) Obstáculos Que Impiden El Fin Del Conflicto En El Chocó. Cien Días Vistos Por CINEP/ PPP 77 (Diciembre 2012-Febrero 2013): 42-47

Gutierrez G (1973) A theology of liberation: history, politics, and salvation. Orbis Books, New York

Halbwachs M (1992) On collective memory. University of Chicago Press, Chicago

Hayes MA, Tombs D (2001) Truth and memory: the church and human rights in El Salvador and Guatemala. Gracewing, Leominster

Henao H (2009) The Colombian church and peacebuilding. In: Bouvier V (ed) Colombia: building peace in a time of war. United States Institute of Peace, Washington, D.C., pp 173-190

Hernandez E (2012) Intervenir Antes de Que Anochezca. Mediaciones, Intermediaciones Y Diplomacias Noviolentas de Base Social En El Conflicto Armado Colombiano. Universidad Autonoma de Bucaramanga, Colombia

Jimenez-Ocampo S, Bello MN, MIllan C, Pulido B (2008) Dinámicas Del Conflicto Y El Desplazamiento Forzado En Chocó: Subregión Medio Atrato Chocuano. Serie Justicia Reparativa Y Desplazamiento Forzado. Colombia, Ediciones Anthropos

Levine DH (2012) Politics, religion, and Society in Latin America. In: Religion in politics and society. Lynne Rienner Publishers, Boulder

Lopez N (2005) Diócesis de Quibdó, Un Alivio a La Crisis Humanitaria de Chocó - Archivo - Archivo Digital de Noticias de Colombia Y El Mundo Desde 1.990. El Tiempo. http://www.eltiempo. com/archivo/documento/MAM-1852356

Losonczy AM (1999) "Memorias E Identidad: Los Negro-Colombianos Del Chocó.” In De Montes, Ríos Y Ciudades: Territorios E Identidades de Gente Negra En Colombia, edited by Juana Camacho and Eduardo Restrepo, 13-23. Bogotá: Ecofondo-Natura-Instituto Colombiano de Antropología

MacLean IS (ed) (2006) Reconciliation, Nations and Churches in Latin America. Ashgate, Aldershot; Burlington

Medellín CELAM. 1968. Conferencia General Del Episcopado Latinoamericano. Conclusiones: La Iglesia En La Actual Transformación de América Latina a La Luz Del Concilio. Secretariado General del CELAM, Bogotá

Miguez Bonino J (1973) Violence: a Theological Reflection. Ecum Rev 25(4):468-474

Misztal, Barbara A (2003) Theories of social remembering. Maidenhead; Philadelphia: Open University Press. http://site.ebrary.com/id/10172378

Pachico, Elyssa (2015) “Construyendo Paz Y Dignidad: La Participación Jesuita En El Magdalena Medio de Colombia.” In Las Iglesias Ante La Violencia En América Latina: Los Derechos Humanos En El Pasado y El Presente, edited by Alexander Wilde, Primera edición en español, 295-322. México: Washington: FLACSO México ; Center for Latin American \& Latino Studies, American University

Palacios M (2006) Between Legitimacy and Violence: A History of Colombia, 1875-2002 (trans:Stoller R). Durham, Duke University Press Books

Perea N (2012) Soy Atrato. Vida Y Amargos Recuerdos de Un Líder Negro. Bojayá Una Década (20022012). Otramerica, Santander

Puebla (1979) 3rd. Latin American General Episcopate Council, Latin American Evangelization in the present and future. CELAM, Puebla

Restrepo E (2002) Memories, identities, and ethnicity: making the black Community in Colombia. University of North Carolina at Chapel Hil, Chapel Hill

Rigney A (2012) Reconciliation and remembering: (how) does it work? Mem Stud 5(3):251-258. https://doi. org/10.1177/1750698012440927 
Rios Oyola S (2015) Religion, Social Memory, and Conflict: The Massacre of Bojayá in Colombia. Palgrave Studies in Compromise after Conflict. Palgrave Macmillan, Hampshire

Rothberg M (2009) Multidirectional Memory: Remembering the Holocaust in the Age of Decolonization. Stanford University Press, Stanford, Calif.

Santo Domingo (1992) 4th Latin American General Episcopate Council, Santo Domingo Conference Document. CELAM, Bogota

Smith C (1991) The emergence of liberation theology: radical religion and social movement theory. University of Chicago Press, Chicago

Steele D (2008) "An introductory overview to faith-based peacebuilding." In Pursuing Just Peace: An Overview and Case Studies for Faith-Based Peacebuilders, edited by Mark M. Rogers, Tom Bamat, and Julie Ideh. Catholic Relief Services

Tate W (2015) "Violencia Y Atención Pastoral En Putumayo, Colombia." In Las Iglesias Ante La Violencia En América Latina: Los Derechos Humanos En El Pasado y El Presente, edited by Alexander Wilde, Primera edición en español, 351-80. México, D.F. : Washington, DC: FLACSO México ; Center for Latin American \& Latino Studies, American University

Wilde A (ed.) (2015) Las Iglesias Ante La Violencia En América Latina: Los Derechos Humanos En El Pasado y El Presente. Primera edición en español. México, D.F.: FLACSO México; Center for Latin American \& Latino Studies, American University, Washington, DC 